\title{
The Attics of My Life: Joy Within the Melancholic Lyrics of John Keats and The Grateful Dead
}

\author{
Susan Peterson \\ Curry College, Milton, Massachusetts, USA
}

\begin{abstract}
This essay is a culmination of intensive research exploring the commonality between Dr. John Keats' poetry and the lyrics of The Grateful Dead. As this is the 50th anniversary of The Grateful Dead, it is appropriate to celebrate that with a scholarly paper. In teaching my course The Grateful Dead as Poets I discovered compelling intersections between English Romantic poetry and the lyrics of The Grateful Dead. These findings are useful and important because the work of the Dead spans five decades and endures in ways that assure their place in literary history as well as the music world. The importance of The Grateful Dead cannot be overstated. They bring hope, love, joy and philanthropy to the world, as did the English Romantic poets. There is much yet to explore; this essay is about only a few of the many Grateful Dead lyrics.
\end{abstract}

Keywords: John Keats, The Grateful Dead, melancholy, optimism, succor

And as, in sparkling majesty, a star Gilds the bright summit of some gloomy cloud Brightening the half veil'd face of heaven afar: So, when dark thoughts my boding spirit shroud, Sweet Hope, celestial influence round me shed, Waving thy silver pinions o'er my head. —John Keats To Hope (1815)

Sometimes the light's all shinin' on me Other time I can barely see Lately it occurs to me What a long strange trip it's been - The Grateful Dead Truckin' (1970)

\section{Introduction}

First, please allow me to explain to you to The Grateful Dead experience. From the time The Grateful Dead were a fledgling rock band playing free concerts in the Haight-Ashbury neighborhood of San Francisco in 1965, to this, their 50th anniversary, they have created the happiest milieu in entertainment. At the pre-show 
"Shakedown Street", vendors sell everything from handmade tie-dyed t-shirts and stickers, to cold beer, veggie burritos, and pot brownies. Impromptu drum circles form in the parking lot where lucky Deadheads seeking a “miracle” (free ticket) actually get one, and the Dead's music playing on car stereos heralds the start of the party. The joyful atmosphere fosters kindness; as the Dead say in their song Scarlet Begonias, the scene is all about "Strangers stoppin' strangers just to shake their hands / Everybody is playing in the heart of gold band" (Garcia, \& Hunter, 1974, lines 23-24). And love is ubiquitous. Whatever nasty cards life has dealt you lately, it is practically impossible to remain depressed at a Dead show. For a few hours the band and their "Deadheads" revel in a time-out from the often unkind circumstances of life. It is a time of pure joy, unlike anything in rock history.

Indeed, having attended many rock shows, I can say with complete certainty that Dead shows are unlike any other experience. Interestingly, they are described perfectly by Keats in Endymion when he says, "Wherein lies happiness? In that which becks / Our ready minds to fellowship divine, / A fellowship with essence; till we shine...” (1818, Bk. I, l. 777). That said, the Dead's lyrics also do address the unhappy realities of life. But as with Keats, this only lends truth to their words.

The poetry of the Dead's lyrics rings with insightful honesty; it is easy to find similarity between their words and those of poets across time and cultures. Still, to compare their lyrics with a genius such as Keats presents both a pleasure and a challenge, especially when the topic is melancholy. There is melancholy in the Dead's lyrics, as in Keats, yet the most precious gift of these artists is that in the crafting of their words hope prevails, and ultimately melancholy is eclipsed by joy.

Keats suffered a plethora of tragic events that effected the melancholic quality of his poetry. Ode to a Nightingale, To Autumn, La Belle Dame Sans Merci and When I Have Fears, Ode on Melancholy, to name but a few, address a range of painful experiences. And yet these lyrics remind us of the resilience of the human spirit. For despite the inevitability of life's painful moments so eloquently described by Keats, his poetry also embodies consolation and hope.

Indeed, Keats' integration of consolation and hope in his poems of melancholy resonates in the lyrics of The Grateful Dead; many of the Dead's songs impart gentle reminders of the dark side of life. The sorrow expressed in Phil Lesh's Box of Rain, Garcia and Hunter's Brokedown Palace, Bob Weir's Looks Like Rain and many other lyrics speak movingly of the human condition of personal heartbreak and loss. Yet despite these sad themes, the Dead's lyrics, like Keats' poetry, are ultimately optimistic at the deepest level.

Keats' biography reads as a tragic journey; his father was killed in an accident when Keats was only eight; his mother, whom he adored, left the family for a time and died of tuberculosis soon after returning to them, when Keats was just fourteen. When he was twenty-three, his brother Tom also died of tuberculosis. And his relationship with Fanny Brawne was destined to end in heartbreak; they loved each other deeply, but Keats was both too sick and too poor to marry her. In 1819 it became clear that Keats, like his mother and brother, had also contracted tuberculosis. He died on February 24th, 1821 at the age of twenty-five.

The members of The Grateful Dead have also suffered tragedy and loss. The bass guitarist, Phil Lesh, lost his father to prostate cancer; arguably, Lesh's most famous composition with Robert Hunter, Box of Rain, reflects this experience with its heart-wrenching verses and description of helplessness in the face of insurmountable illness. Guitarist Bob Weir lost both of his parents by the time he was twenty-five, also to cancer. The original keyboardist of the band, Ron "Pigpen” McKernan, died of complications from alcoholism in 1973, and the three 
keyboardists who succeeded him also died tragically and young. (In an interview with Vince Welnick, the last keyboardist to play with The Grateful Dead, he was asked what he was going to do in his spare time. He said, "Buy life insurance.”) The great friend and producer of The Grateful Dead shows, Bill Graham (founder of Bill Graham Presents-not to be confused with the well-known preacher) was killed in a helicopter crash in 1991. His death left the band members reeling.

Yet by far the most tragic event for The Grateful Dead was the death of lead guitarist, Jerry Garcia, in August of 1995 after a long struggle with drug addiction, heart disease and diabetes. And yet, Jerry was found with a blissful smile on his face, as if he wanted to leave that final offering to all those who love and miss him deeply. Thus, even within the cruel sorrow of his parting, joy was present. Joy is the message Jerry left us with, echoing that of John Keats. For at certain moments during Keats' struggle with his imminent death, it was nevertheless finally welcome. In Ode to a Nightingale he says:

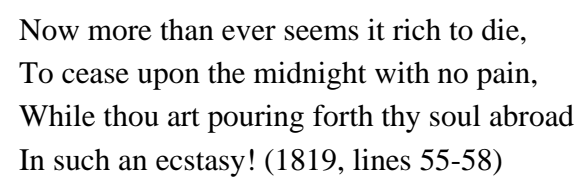

The many tragedies suffered by both John Keats and The Grateful Dead color their poetry in thematically similar and quite extraordinary ways. In Keats' La Belle Dam Sans Merci he writes:

I met a lady in the meads,

Full beautiful—a faery's child,

Her hair was long, her foot was light,

And her eyes were wild.

I made a garland for her head,

And bracelets too, and fragrant zone;

She looked at me as she did love,

And made sweet moan...

...I saw pale kings and princes too,

Pale warriors, death-pale were they all;

They cried-'La Belle Dame sans Merci

Thee hath in thrall!'

And this is why I sojourn here,

Alone and palely loitering,

Though the sedge is withered from the lake,

and no birds sing. (1820a, lines 13-48)

In Bob Weir's Looks Like Rain he says:

I only want to hold you; I don't want to tie you down

Or fit you in the lines I might've drawn.

It's just that I, oh I, have gotten used to havin' you around.

The landscape would be empty, if you were gone;

But it's alright 'cause I love you, and that's not going to change.

Run me around and make me hurt again and again.

But I'll still sing you love songs, written in the letters of your name.

The rain is gonna come, oh it surely looks like rain. (1990, lines 13-20) 
Common to both lyrics is the deep desire to possess what one never can. While Weir's speaker at first seems tentatively hopeful that his lover will return, the final line, "The rain is gonna come, oh it surely looks like rain" (1990, line 20) makes it clear he knows she never will. Keats' knight also knows his faery has abandoned him; he is warned by the other knights, "Pale warriors, death-pale were they all; / They cried-'La Belle Dame sans Merci / Hath thee in thrall!” (1820a, lines 38-40). The speakers in both lyrics vividly describe their fear and pain such that it becomes palpable to the reader, and frightening for its inevitability as part of the human experience.

In his Ode to a Nightingale Keats rails against fate; he says:

Forlorn! the very word is like a bell

To toll me back from thee to my sole self!

Adieu! the fancy cannot cheat so well

As she is fam'd to do, deceiving elf.

Adieu! adieu! thy plaintive anthem fades

Past the near meadows, over the still stream,

Up the hill-side; and now 'tis buried deep

In the next valley-glades:

Was it a vision, or a waking dream?

Fled is that music: —Do I wake or sleep? (1819, lines 71-80)

Robert Hunter and Jerry Garcia’s Brokedown Palace echoes Keats’ desire to seek solace from the natural world in the lines:

Fare you well my honey

Fare you well my only true one

All the birds that were singing

Have flown except you alone

Goin' to leave this Brokedown Palace

On my hands and my knees I will roll roll roll

Make myself a bed by the waterside

In my time- in my time- - I will roll roll roll. (1970a, lines 1-8)

Keats' speaker is abandoned by Fate; so too is Garcia and Hunter's. In both lyrics, the characters also experience confusion. Keats writes that he cannot discern between the states of sleep and wakefulness, while the speaker in Brokedown Palace must "roll...on my hands and knees" to the waterside. Neither character can live fully in the unbearable reality they find themselves ensconced in; both seek escape to simplicity and solitude. As readers, we can imagine both their suffering and the solace they seek from the natural world.

Keats' poem When I Have Fears That I May Cease to Be culminates in a description of the journey towards death. He says, “...then on the shore / Of the wide world I stand alone, and think / Till love and fame to nothingness do sink” (1848, lines 12-14). Life contracts—for Keats, whatever measure of fame he has earned in his lifetime becomes meaningless. Even love finally loses its hold on his emotions; the longing it engenders cannot be sustained in the face of death, for death overshadows all other experiences and emotions. Keats says, "Is there another life? Shall I awake and find all this a dream? There must be, we cannot be created for this sort of suffering” (letter to Charles Brown, Sep. 30, 1820).

Indeed, Keats asked that his tombstone bear the inscription "Here Lies One Whose Name was writ in Water." As in Ode to a Nightingale, Keats' request acknowledges the transient nature of life and even of memory 
itself. As well, the deep sadness expressed in When I Have Fears is ultimately diminished by the imminence of death because for Keats this realization does not necessarily engender hopelessness, but rather, a desire to focus on the mysterious journey of death.

Death is unfathomable, too, to those who must bear witness to it. Phil Lesh and Robert Hunter's Box of Rain, written in tribute to Lesh's dying father, offers a window into the sense of helplessness we experience when someone we love is dying. Lesh sings:

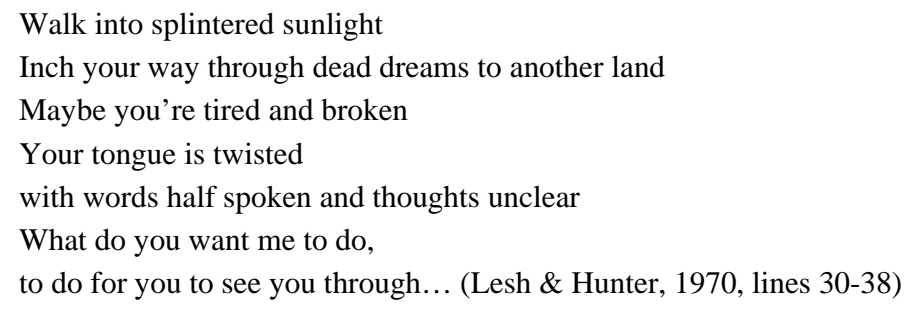

The question in the lines "What do you want me to do / to do for you to see you through" seeks a response from the one advancing towards death, but who can never truly answer it. For death is the most profoundly personal journey; as it approaches, desires transition into essential needs - the cessation of pain, the awareness of being deeply loved. So the answer to the song's question is the offering of love, the truest thing in one's final moments on this "box of rain". For in this lyric the "box of rain" is a metaphor for the natural world. Robert Hunter says, “By 'box of rain,' I meant the world we live on, but 'ball' of rain didn't have the right ring to my ear, so box it became, and I don't know who put it there” (Dodd, 2007). Thus the solace of nature, the essence of Romanticism, is integral to the song in the lines, "A box of rain will ease the pain /and love will see you through" (Lesh \& Hunter, 1970, lines 39-40).

The lyrics of Garcia and Hunter's Ripple resonate with Keats' To Autumn. Ripple's lyrics describe the journey towards death as one that is not to be feared, but embraced:

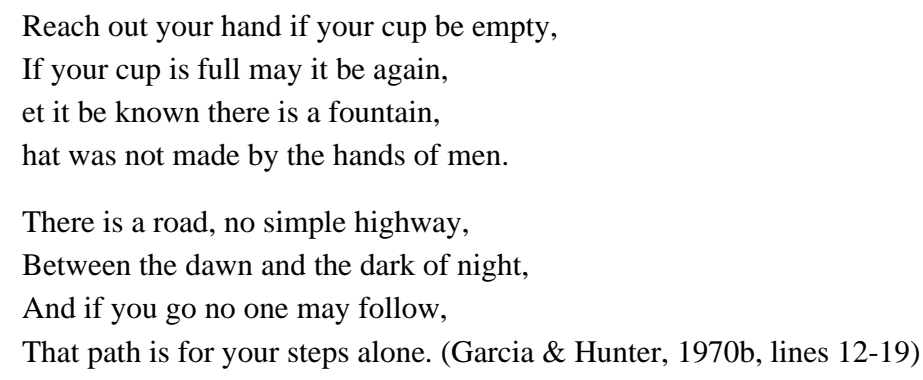

The fountain represents eternal abundance, but the lyric also acknowledges that although the universe is bountiful, there are times in life when it certainly does not seem to be. Yet still the message of hope endures, for even in the darkest moments succor is at hand.

In Keats’ To Autumn he says:

Where are the songs of Spring? Ay, where are they?

Think not of them, thou hast thy music too, -

While barred clouds bloom the soft-dying day,

And touch the stubble-plains with rosy hue;

Then in a wailful choir the small gnats mourn 
Among the river sallows, borne aloft

Or sinking as the light wind lives or dies;

And full-grown lambs loud bleat from hilly bourn;

Hedge-crickets sing; and now with treble soft

The redbreast whistles from a garden-croft,

And gathering swallows twitter in the skies. (1820c, lines 23-33)

As for The Grateful Dead, for Keats abundance is illustrated by the gifts of the fading year, just as there are gifts to be found at the end of human life. In his description of the "music" of spring, the season of re-birth and renewal; he makes it clear that this is not the sole precious season of life. For autumn "hast thou music too" as Keats depicts with his description of the beauty of the autumnal landscape around him. For him, the culmination of hope lies within that season, the season of abundance. And in the end the swallows, symbolic of the human soul, take flight and are free, beginning a journey of hope, not of regret, and certainly not of grief. They wing joyfully to the skies.

Finally, in Scarlet Begonias The Grateful Dead capture the resilience of the human spirit, the hope, the joy of their time, even as Keats did in his. They sing, "Once in a while you get shown the light / In the strangest of places if you look at it right” (1974, lines 15-16). Keats’ poetry and the lyrics of The Grateful Dead, while acknowledging the melancholic aspects inherent to human existence, more importantly entice us to realize that the light can eclipse the darkness - if we only look at it right.

\section{Conclusion}

Despite the many hardhips and tragedies that John Keats and the individual members of The Grateful Dead endured, their lyrics speak eloquently, rather than bitterly about those experiences. Their perspectives regarding these many tragic events ring with hope and beauty and ultimately, with thoughtful acceptance of the dark aspects of the human condition. Within this poetry one can find comfort and even discover inspiration to creatively respond to the melancholic events that all humans must endure. As Keats says in To Autumn, "Where are the songs of spring? Aye, where are they? Think not of them; thou hast thy music too-” (1820, Book 3). Just as Autumn presents its own delights, so too can we find hope and joy in every aspect of life. The Grateful Dead reflect Keats' lyrical style, creating the music that plays to the emotions so germane in their libretto. For as Keats says in Sleep and Poetry:

And they shall be accounted poet kings

Who simply tell the most heart-easing things.

O may these joys be ripe before I die. (1884, pp. 267-269)

\section{References}

Dodd, D. (2007). The annotated grateful dead lyrics. New York: Free Press.

Garcia, J., \& Hunter, R. (June 27, 1974). Scarlet begonias. From the mars hotel. On The annotated grateful dead lyrics. San Francisco: Grateful Dead Records.

Garcia, J., \& Hunter, R. (November 1970a). Brokedown palace. American beauty. On The annotated grateful dead lyrics. San Francisco: Warner Bros.

Garcia, J., \& Hunter, R. (November 1970b). Ripple. American beauty. On The annotated grateful dead lyrics. San Francisco: Warner Bros. 
Garcia, J., \& Hunter, R. (November 1970c). Truckin'. American beauty. On The annotated grateful dead lyrics. San Francisco: Warner Bros.

Garcia, J., \& Hunter, R. (November 1978). Shakedown street. Shakedown street. On The annotated grateful dead lyrics. New York: Arista Records.

Keats, J. (1815). To hope. London: The Examiner.

Keats, J. (1818). Endymion. London: Taylor and Hessey.

Keats, J. (1819). Ode to a nightingale. London: Annals of the Fine Arts.

Keats, J. (1820a). La belle dame sans merci. London: The Indicator.

Keats, J. (1820b). Ode on melancholy. London: Taylor and Hessey.

Keats, J. (1820c). To autumn. London: Taylor and Hessey.

Keats, J. (1848). When I have fears that I may cease to be. London: Edgard Moxon.

Keats, J. (1884). Sleep and poetry. London: Macmillan.

Lesh, P., \& Hunter, R. (November 1970). Box of rain. American Beauty. On The annotated grateful dead lyrics. San Francisco: Warner Bros.

Weir, B. (September 1990). Looks like rain. Without A Net. On The annotated grateful dead lyrics. New York: Arista Records. 